\title{
Study on the Planning of Airport Logistics Park in a City
}

\author{
Zilin Nie \\ School of Economics and Management \\ Beijing Jiaotong University \\ Beijing, China
}

\author{
Dongkun Duan \\ School of Economics and Management \\ Beijing Jiaotong University \\ Beijing, China
}

\author{
Jiayi Yao \\ School of Economics and Management \\ Beijing Jiaotong University \\ Beijing, China
}

\begin{abstract}
With the rapid development of the international airport in a certain city in recent years, a city aviation port has emerged. The planning and construction of logistics parks and the rationality of the layout of each functional area are directly related to the horizontal extension of the aviation logistics industry in the future, the operational efficiency of logistics parks, and trade transactions. Based on the annual cargo throughput of a city's airport logistics park, this paper designs the functional areas of the Airport Logistics Park, and uses the Systematic Layout Planning (SLP) to design and plan each functional area to achieve resource conservation and efficient operation of the Airport Logistics Park. Objectively, and provide theoretical and application guidance for the future construction of aviation logistics parks.
\end{abstract}

Keywords-facility planning; SLP; logistics

\section{INTRODUCTION}

The practice of international aviation logistics development shows that airport logistics parks can achieve efficient logistics operations, attract a large number of airlines and logistics companies to settle in, help the development of air cargo and the formation of cargo hubs, and improve the supply chain system and regional economy. The development can also promote the development of related industries. Only by adopting scientific and effective methods and rationally positioning the functions and planning of the logistics park can we ensure smooth operation after its completion [1]. Therefore, this paper will adopt the layout method of SLP and apply the logistics area functional area layout model to the real cases. Through the research of this thesis, it can provide theoretical research reference and support for the layout planning of logistics park functional areas.

\section{SWOT ANALYSIS OF AN AIRPORT LOGISTICS PARK IN A CITY}

\section{A. Advantages}

The aviation logistics park mainly develops the air logistics industry. As of the end of 2016, an international airport in the city opened a total of 162 passenger routes, which has become the fourth largest freight airport in the country except Shanghai Pudong, Guangzhou Baiyun and Shenzhen Bao'an Airport.

Learning from the "Study on Multimodal Transport Planning of a City's Airports" and "Architecture Layout and Planning of the Shenzhen Logistics Park" and "Study on the Planning and Layout of the Facilities of a Airport Logistics Park in a City", the number of goods and passengers that stayed here was considerable, which all explained This airport has a huge potential for the development of logistics parks [2].

\section{B. Disadvantages}

The throughput of an international airport in a city is lower than that of other large international airports in China. The development of routes is insufficient, and the investment in aviation power is relatively small, which can not drive the rapid development of airports. Route resources are also one of the important indicators for airport selection. However, due to the dynamic conditions of Xinzheng Airport, it is impossible to maintain the status of working all the time. Therefore, it is still not possible to undertake the entry of some large-scale international projects.

\section{Threats Faced with}

At present, the provinces of Anhui, Shanxi, Hebei, Hubei, and Shandong, which are close to a certain province, have all realized the importance of developing aviation logistics. Each has formulated its own development plan for the airport logistics park. The five central provinces are scrambling to 
build their own aviation logistics parks, making the airport logistics park in a city more difficult to attract foreign investment and attract foreign investors.

\section{Opportunity Analysis}

According to the "13th Five-year Plan" for the development of a modern logistics industry in a province, the development scale of the international airport logistics industry will be further expanded during the "13th Five-year Plan" period [3].

On the other hand, the Central Plains City Cluster Strategy is an important practice for the implementation of the strategic planning of the Central Plains Economic Zone by a provincial party committee and the provincial government. The integration of inland cities will promote an important demonstration of the hub status of a city's airport and promote the integration of logistics in the park. Development provides a vast space for development for the aviation logistics industry [4].

\section{Plan DESIGN OF FunCtional AREA LAYOUT} PLANNING FOR AN AIRPORT LOGISTICS PARK IN A CERTAIN CITY

\section{A. The Functional Area of a Logistics Zone in a City's Airport Area Is Determined}

To fulfill the function of the aviation logistics park function area, it must include the following seven functional areas: airport cargo area, bonded logistics area, international procurement trade area, international transit distribution area, circulation value-added processing area, comprehensive supporting area, information Service area [5].

- Airport cargo area: Provide the city's airport receiving, delivery, cargo handling, temporary storage and other areas; including the airport's public cargo terminals, airline base freight stations, cargo handling platforms, customs inspection and acceptance warehouses.

- Bonded Logistics Zone: This is an indispensable area for an airport logistics park in a city. The bonded area is developed in China's airport logistics parks. It is mainly used to provide bonded services for customs import and export goods. It consists of bonded warehouses, inspection stations, and buckles.

- International Purchase Trade Area: This area is mainly for international cargo entering and leaving the airport.

- International transit distribution area: The aviation logistics park utilizes special policies granted by the customs to distribute, distribute, distribute, distribute, and distribute distribution services for imported bonded goods.

- Value-added processing area: It includes auxiliary simple operations such as grading, sorting, sorting, dispensing, metering, packaging, filming, brushing, marking, and changing packaging and assembling.
- Comprehensive supporting area: serving aviation, freight forwarding, logistics companies, while meeting the business and living needs of staff and air travelers in the region.

- Information service area: including the provision of bonded logistics center warehousing information, customs declaration, inspection and inquiries, logistics policy information, logistics program planning, and weather, surrounding traffic conditions and other related information services.

\section{B. Correlation Analysis of Function Zones in Airport Logistics Parks}

1) Analysis of logistics interrelationships in functional areas: According to the online search data obtained the prediction of the annual cargo throughput of a city's airport logistics park from 2011 to 2016 (see "Table I"), the cargo throughput in the next three years from 2017 to 2022 is obtained (see "Table II").

TABLE I. CARgo Throughrut OF AIR PORT Logistics PARK IN A CITY IN RECENT YEARS

\begin{tabular}{|l|l|l|}
\hline \multicolumn{1}{|c|}{ years } & \multicolumn{1}{|c|}{$\begin{array}{c}\text { Freight throughput } \\
\text { (tons) }\end{array}$} & Year-on-year (\%) \\
\hline 2011 & 102802.6 & 19.82 \\
\hline 2012 & 151193.5 & 47.07 \\
\hline 2013 & 255712.8 & 69.13 \\
\hline 2014 & 370420.8 & 44.86 \\
\hline 2015 & 403339 & 8.89 \\
\hline 2016 & 456700 & 13.2 \\
\hline
\end{tabular}

TABLE II. FORECAST OF CARGO THROUGHPUT IN 2017 2019 AIRPORT LOGISTICS PARK

\begin{tabular}{|l|l|l|}
\hline \multicolumn{1}{|c|}{ years } & \multicolumn{1}{|c|}{$\begin{array}{c}\text { Forecast cargo } \\
\text { throughput (tons) }\end{array}$} & \multicolumn{1}{|c|}{$\begin{array}{c}\text { Year-on-year } \\
\text { increase (\%) }\end{array}$} \\
\hline 2017 & 501346.56 & 9.8 \\
\hline 2018 & 566521.61 & 13 \\
\hline 2019 & 651499.8547 & 15 \\
\hline 2020 & 729679.93 & 12 \\
\hline 2021 & 793161 & 8.7 \\
\hline 2022 & 874064.5 & 10.2 \\
\hline
\end{tabular}

Through statistical analysis of the daily admission flow of goods in a city's airport logistics park, it was found that all cargo first arrived at the air cargo area, $48 \%$ of the goods entered the international transit distribution area directly, $20 \%$ entered the bonded warehouse directly, and another $16 \%$ entered the value-added processing area. About $14 \%$ of the value-added processing zones are flown to the international purchasing trade zone. In the bonded warehouse area, $78 \%$ of the same day's entry volume enters the international transit distribution area every day, and $20 \%$ enter the international purchasing trade area. The valueadded processing area receives $56 \%$ of the daily access volume and enters the international transit distribution area every day, $20 \%$ enter the bonded logistics area, and $78 \%$ of the international procurement trade area has entered the international transit distribution area.

According to the statistics of the amount of material flow, the logistics intensity levels between the logistics functional 
area units are divided, as shown in "Table III", and for each functional area with no logistics intensity, their logistics intensity level Set to U-level.

TABLE III. CLASSIFICATION OF LOGISTICS INTENSITY BETWEEN FUNCTIONAL AREAS

\begin{tabular}{|c|c|c|c|}
\hline Functional Area Pair & $\begin{array}{c}\text { Flow of } \\
\text { material } \\
\text { (tons) }\end{array}$ & $\begin{array}{l}\text { Proportion } \\
(\%)\end{array}$ & $\begin{array}{l}\text { Grade } \\
\text { intensity }\end{array}$ \\
\hline $\begin{array}{lr}\text { Airport cargo } & \text { area } \\
\text { International } & \text { transit } \\
\text { distribution area } & \end{array}$ & 1149.5 & 28.6 & $\mathrm{~A}$ \\
\hline $\begin{array}{l}\text { Airport cargo area - bonded } \\
\text { warehouse area }\end{array}$ & 478.9 & 11.9 & $\mathrm{E}$ \\
\hline $\begin{array}{llr}\text { Airport } & \text { Port Logistics - } \\
\text { Value } & \text { Added } & \text { Processing } \\
\text { Zone } & & \\
\end{array}$ & 383.2 & 9.5 & $E$ \\
\hline $\begin{array}{l}\text { Airport Port International - } \\
\text { Purchase and Trade Zone }\end{array}$ & 335.2 & 8.3 & $\mathrm{I}$ \\
\hline $\begin{array}{lr}\text { Bonded warehouse } & \text { area }- \\
\text { international } & \text { transit } \\
\text { distribution area } & \\
\end{array}$ & 896.6 & 22.3 & $\mathrm{~A}$ \\
\hline $\begin{array}{l}\text { Value-added processing zone } \\
\text { - international transit } \\
\text { distribution area }\end{array}$ & 214.6 & 5.3 & $\mathrm{O}$ \\
\hline $\begin{array}{l}\text { Bonded Warehouse District } \\
\text { — -International Procurement } \\
\text { Trade Area }\end{array}$ & 229.9 & 5.7 & I \\
\hline $\begin{array}{l}\text { Value-added processing zone } \\
- \text { bonded warehouse area }\end{array}$ & 76.6 & 2.0 & $\mathrm{O}$ \\
\hline $\begin{array}{l}\text { International purchasing trade } \\
\text { zone - international transit } \\
\text { distribution area }\end{array}$ & 261.5 & 6.4 & I \\
\hline
\end{tabular}

2) Non-logistical relationship analysis in functional areas: There are many non-logistic relations affecting the layout of functional areas of logistics parks. The influencing factors of non-logistic relations in this paper are mainly analyzed and researched from the following six aspects. The specific influencing factors and their numbers are shown in "Table IV" below.

TABLE IV. FACTORS AFFECTING NON-LOGISTIC RELATIONS IN FUNCTIONAL AREAS

\begin{tabular}{|l|l|}
\hline No. & \multicolumn{1}{|c|}{ Non-logistics Reasons } \\
\hline 1 & Logistics related, continuous \\
\hline 2 & Logistics job similarity \\
\hline 3 & Frequency of logistics operations \\
\hline 4 & Material handling \\
\hline 5 & Supervision and management convenience \\
\hline 6 & Environmental issues such as noise, trash, and dust \\
\hline
\end{tabular}

Therefore, based on these six influencing factors, the closeness of this non-logistic relationship among the functional areas can be divided into the following levels, as shown in the "Table V" below.
TABLE V. REASONS FOR THE ClaSSIFICATION OF NON-LOGISTIC RELATIONS AMONG FUNCTIONAL AREAS IN AIRPORT LOGISTICS PARKS

\begin{tabular}{|l|l|}
\hline \multicolumn{1}{|c|}{$\begin{array}{c}\text { Non-logistic } \\
\text { intensity level }\end{array}$} & $\begin{array}{l}\text { Rrom the airport cargo shipping area to the } \\
\text { international transit distribution area, and from the } \\
\text { bonded warehouse area to the international transit } \\
\text { distribution area, logistics operations are relatively } \\
\text { high, so they are relatively close. }\end{array}$ \\
\hline $\mathrm{E} / 4$ & $\begin{array}{l}\text { From the airport cargo shipping area to the bonded } \\
\text { warehouse area, and from the international } \\
\text { purchasing trade area to the international transit } \\
\text { distribution area, there are many more things } \\
\text { involved in the handling of the logistics, and the } \\
\text { operation intensity is large and the layout is close. }\end{array}$ \\
\hline $\mathrm{I} / 1, \mathrm{I} / 3, \mathrm{I} / 5$ & $\begin{array}{l}\text { This mainly involves the handling, dismantling of } \\
\text { large containers, the processing of goods, and the } \\
\text { comprehensive support of personnel exchanges. The } \\
\text { cargo is heavy, but not much, and the flow of } \\
\text { people is large. }\end{array}$ \\
\hline $\mathrm{O} / 1, \mathrm{O} / 3, \mathrm{O} / 5$ & $\begin{array}{l}\text { This mainly involves the handling of goods, but the } \\
\text { volume is relatively small, it also involves the } \\
\text { information management of freight transportation in } \\
\text { the storage area, and the position can be } \\
\text { appropriately estranged. }\end{array}$ \\
\hline $\mathrm{U} / 1, \mathrm{U} / 3, \mathrm{U} / 6$ & $\begin{array}{l}\text { There will be a small number of goods circulating, } \\
\text { but the amount is relatively small, or there is no } \\
\text { necessary connection between the two functional } \\
\text { areas. }\end{array}$ \\
\hline
\end{tabular}

a. Note: The following serial number represents the reason for the non-logistic relationship of "Table

3) Analysis of comprehensive relationships: In order to objectively explain the relationship between functional areas, this paper will use the weighted average method to quantify the logistics relationship and non-logistic relationship in the functional areas, and obtain the distribution table of the comprehensive relationship grades of functional areas.

TABLE VI. QUANTITATIVE ANALYSIS OF THE COMPREHENSIVE RELATIONSHIP IN FUNCTIONAL ZONES OF LOGISTICS PARKS

\begin{tabular}{|c|c|c|c|c|c|}
\hline \multirow[t]{2}{*}{$\begin{array}{l}\text { Functional } \\
\text { area pairs }\end{array}$} & \multicolumn{2}{|c|}{$\begin{array}{l}\text { Logistics } \\
\text { relationship } \\
\quad(\mathbf{m}=\mathbf{3})\end{array}$} & \multicolumn{2}{|c|}{$\begin{array}{c}\text { Non-logistic } \\
\text { relationship } \\
\quad(n=1)\end{array}$} & \multirow{2}{*}{$\begin{array}{c}\begin{array}{c}\text { Comprehensive } \\
\text { relationship } \\
(\mathrm{CRij}=\mathrm{mMRij} \\
\text { nNRij) }\end{array} \\
\text { Score (CRij) }\end{array}$} \\
\hline & grade & $\begin{array}{c}\text { Score } \\
\text { (MRij) }\end{array}$ & grade & $\begin{array}{l}\text { Score } \\
\text { (NRij) }\end{array}$ & \\
\hline $1-2$ & A & 4 & A & 4 & 16 \\
\hline $1-3$ & $E$ & 3 & $E$ & 3 & 12 \\
\hline$\cdots$ & $\cdots$ & $\cdots$ & $\cdots$ & $\cdots$ & $\cdots$ \\
\hline $2-3$ & A & 4 & A & 4 & 16 \\
\hline $2-4$ & $\mathrm{O}$ & 1 & $\mathrm{O}$ & 1 & 4 \\
\hline$\cdots$ & $\cdots$ & $\cdots$ & $\cdots$ & $\ldots$ & $\ldots$ \\
\hline $3-4$ & $\mathrm{O}$ & 1 & I & 2 & 5 \\
\hline $3-5$ & I & 2 & $\mathrm{O}$ & 1 & 7 \\
\hline$\cdots$ & $\cdots$ & $\cdots$ & $\cdots$ & $\cdots$ & $\cdots$ \\
\hline $4-5$ & $\mathrm{U}$ & 0 & $\mathrm{U}$ & 0 & 0 \\
\hline$\cdots$ & $\cdots$ & $\cdots$ & $\cdots$ & $\cdots$ & $\cdots$ \\
\hline
\end{tabular}




\begin{tabular}{|c|c|c|c|c|c|}
\hline \multirow[t]{2}{*}{$\begin{array}{l}\text { Functional } \\
\text { area pairs }\end{array}$} & \multicolumn{2}{|c|}{$\begin{array}{l}\text { Logistics } \\
\text { relationship } \\
\quad(\mathbf{m}=\mathbf{3})\end{array}$} & \multicolumn{2}{|c|}{$\begin{array}{l}\text { Non-logistic } \\
\text { relationship } \\
\quad(n=1)\end{array}$} & \multirow{2}{*}{$\begin{array}{c}\text { Comprehensive } \\
\text { relationship } \\
\begin{array}{c}\text { (CRij=mMRij } \\
\text { nNRij) }\end{array} \\
\text { Score }(\text { CRij) }\end{array}$} \\
\hline & grade & $\begin{array}{c}\text { Score } \\
\text { (MRij) }\end{array}$ & grade & $\begin{array}{l}\text { Score } \\
\text { (NRij) }\end{array}$ & \\
\hline $5-6$ & $\mathrm{U}$ & 0 & I & 2 & 2 \\
\hline $5-7$ & $\mathrm{U}$ & 0 & $E$ & 3 & 3 \\
\hline $6-7$ & $\mathrm{U}$ & 0 & $\mathrm{X}$ & -1 & -1 \\
\hline
\end{tabular}

TABLE VII. Distribution List OF FUnCTIONAL AREA RATINGS

\begin{tabular}{|l|l|l|l|l|l|}
\hline Score & Number & $\begin{array}{c}\text { The total } \\
\text { percenta } \\
\text { ge (\%) }\end{array}$ & $\begin{array}{c}\text { Percentage } \\
\text { accumulati } \\
\text { on (\%) }\end{array}$ & $\begin{array}{c}\text { Level } \\
\text { deter } \\
\text { minat } \\
\text { ion }\end{array}$ & $\begin{array}{c}\text { Functio } \\
\text { nal area } \\
\text { pairs }\end{array}$ \\
\hline 16 & 2 & 9.5 & 9.5 & A & $1-2,2-3$ \\
\hline 12 & 1 & 4.8 & 14.3 & E & $1-3$ \\
\hline$\ldots$ & $\ldots$ & $\ldots$ & $\ldots$ & $\ldots$ & $\ldots$ \\
\hline 7 & 2 & 9.5 & 33.4 & I & $1-5,3-5$ \\
\hline$\ldots$ & $\ldots$ & $\ldots$ & $\ldots$ & $\ldots$ & $\ldots$ \\
\hline 2 & 2 & 9.5 & 62 & O & $2-7,5-6$ \\
\hline$\ldots$ & $\ldots$ & $\ldots$ & $\ldots$ & $\ldots$ & $\ldots$ \\
\hline-1 & 1 & 4.8 & 100 & U & $6-7$ \\
\hline sum & 21 & 100 & & & \\
\hline
\end{tabular}

\section{Design of Plan Layout of Airport Logistics Park in a Certain City}

The positions are arranged in descending order of the comprehensive relationship level, resulting in the position correlation (see "Fig.1").

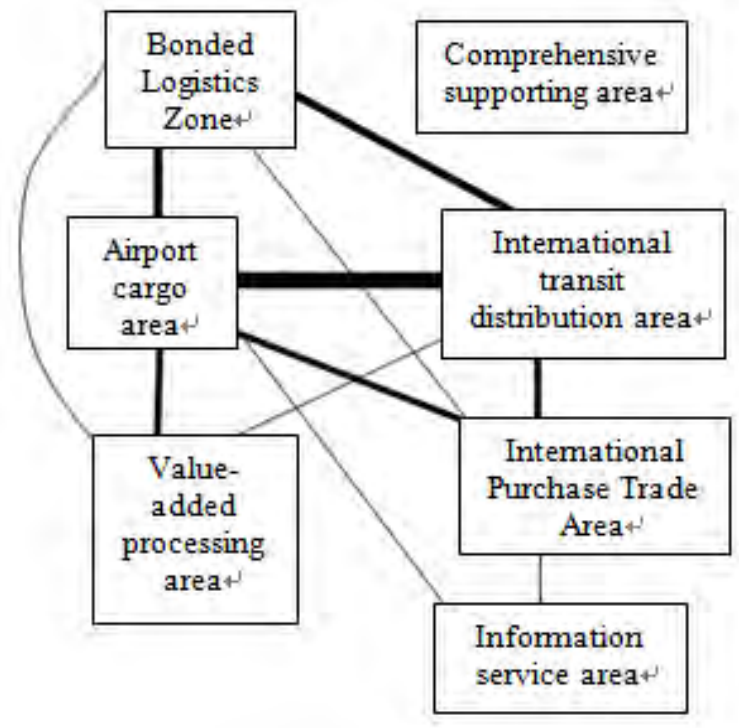

Fig. 1. The position correlation figure.

In the plan layout design of the logistics park, the resulting location-related map was adjusted and mapped into a plan, and the plan for the layout of an airport logistics park in a city is shown in the following "Fig. 2":

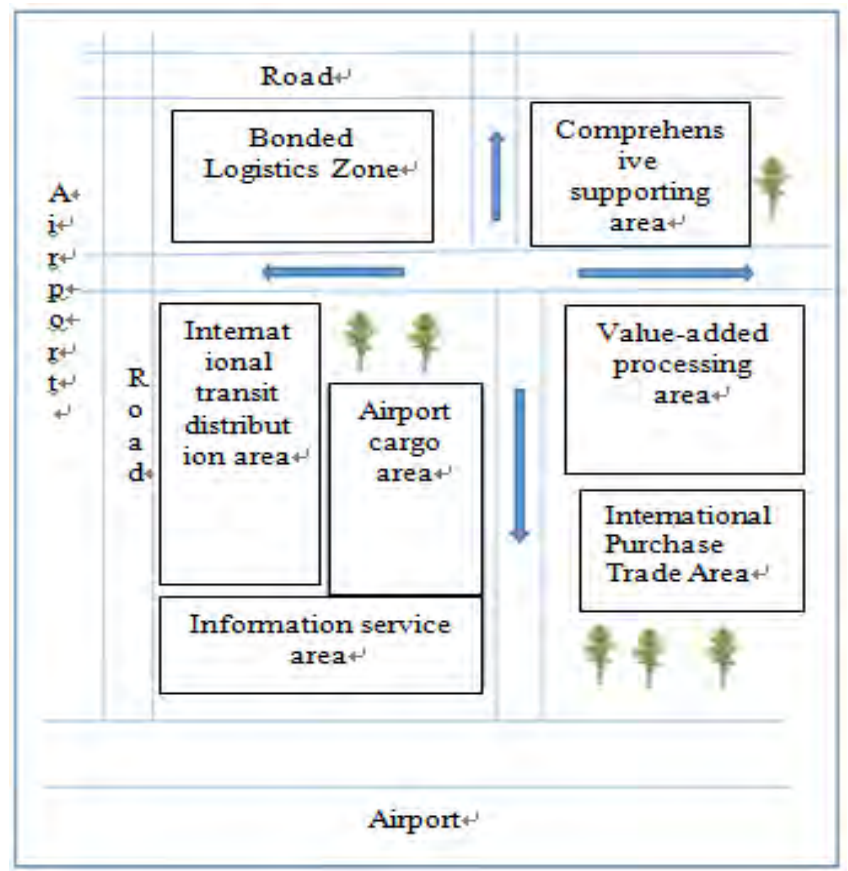

Fig. 2. Plan layout plan of an airport logistics park in a city.

\section{CONCLUSION}

The planning and construction of a logistics park in a city's airport will be operated later, and it will also play an important role in promoting regional economic development. Based on the development requirements of a city's airport logistics park, this paper proposes to use a system layout design method to plan a city's airport logistics park. After understanding the basic conditions of the construction and use of a city's airport logistics park and finding relevant data, the existing logistics parks at home and abroad were found to compare the existing problems of an airport logistics park in a city. This will be used as a breakthrough to study and influence the construction of logistics parks. The influencing factors are applied to the SLP. Therefore, this paper gives a detailed description of the function zone setting and layout application of the logistics park. This is based on a certain theoretical basis and the results of quantitative analysis, and has a strong practicality. And it has a certain reference role for the future planning of logistics park construction.

\section{REFERENCES}

[1] Wang Ke. Research and Application of Hub-type Airport Logistics Park Planning [D]. Shanghai: Shanghai Jiaotong University, 2006.

[2] Cheng Bo. Analysis of the Development of Airport Economy - A Case Study of Zhengzhou Airport Harbor Economic Comprehensive Experimental Area [J]. Science and Wealth, 2016, 4:483-483.

[3] Wu Yongjun. To build a new round of development in Zhengzhou port area of aviation city[J]. Zhongzhou Construction, 2017, 12:29-34.

[4] Liu Fang. Research on the Construction of Zhengzhou Airport's Economic Comprehensive Experimental Area from the Perspective of Global Tourism[J]. Modern Business, 2017, 12: 72-74.

[5] Gu Zhe, Xia Nankai. Functional block layout of Airport Logistics Park [J]. Economic Geography, 2008.28(2):283-285 